\title{
PELANGGARAN SIARAN TELEVISI LOKAL DAN PEMBERIAN SANKSI OLEH KPID SULSEL DI KOTA MAKASSAR
}

\author{
Oleh : ${ }^{1}$ Andriansyah, ${ }^{2}$ Andi Alimuddin Unde, ${ }^{3}$ Hasrullah \\ ${ }^{1}$ Universitas Islam Makassar \\ ${ }^{23}$ Universitas Hasanuddin \\ Email :andriansyah.fisip@uim-makassar.ac.id
}

\begin{abstract}
Abstrak
Televisi Lokal di Makassar sering melakukan pelanggaran P3SPS dan berulang-ulang pada pelanggaran yang sama hal ini berdasarkan ekspose hasil monitoring KPID Sulsel. Penelitian ini bertujuan untuk mengetahui pelanggaran isi siaran yang dominan yang dilakukan oleh televisi lokal, bagaimana KPID Sulsel dalam mengelola sanksi, serta strategi kebijakan KPID Sulsel dalam meminimalisir pelanggaran. Desain penelitian adalah deskriptif kualitatif melalui pengamatan langsung terhadap objek dengan mewawancarai Komisioner KPID Sulsel dan Ketua KPI Pusat serta kajian pustaka. Data dianalisis dengan menggunakan tabel frekuensi dan memperhatikan kebijakan komunikasi yang diambil oleh KPID Sulsel dalam meminimalisir pelanggaran isi siaran. Hasil penelitian ini menunjukkan bahwa pelanggaran televisi lokal yang paling dominan didapatkan oleh KPID Sulsel adalah Pelanggaran Penggolongan Program Siaran. Untuk tahun 2014 terdapat 17.392 pelanggaran dan tahun 2015 terdapat 15.306 pelanggaran. Pengelolaan sanksi KPID Sulsel tidak maksimal karena perbedaan yang sangat siginifikan antara pelanggaran dengan pemberian sanksi dan strategi kebijakan yang dikeluarkan oleh KPID Sulsel adalah kebijaksanaan terkait penempatan penggolongan program siaran, serta melakukan sosialisasi, pelatihan dan pembinaan kepada lembaga penyiaran melalui program kegiatan antara lain GESIT, KPID AWARD, FGD serta Literasi Media kepada Masyarakat melalui Program Kegiatan GEMES, FMPPS.
\end{abstract}

Kata kunci: Televisi Lokal, Pelanggaran Isi Siaran, Penggolongan Program Siaran, P3SPS. 


\section{A. PENDAHULUAN}

Kemajuan tekonologi komunikasi dan informasi membuat industri media massa semakin pesat. Negara-negara maju yang mempelopori industri media massa ini bukan lagi menjadi pemain tunggal. Dengan semakin menyebarnya teknologi tersebut, maka makin menyebar pula pemanfaatan teknologi dalam media massa. Bermula dari makin maraknya penggunaan teknologi komunikasi dalam industri media inilah yang menjadikan globalisasi media tak terlakkan lagi. Pada jaman yang seringkali disebut sebagai the information age ini, media massa tidak lagi dimonopoli oleh negara-negara besar.

Sebagai salah satu media massa yang digunakan dalam proses komunikasi, televisi memiliki kelebihan karena sifatnya yang langsung, tidak mengenal jarak dan memiliki daya tarik yang kuat. Langsung di sini berarti suatu pesan yang disampaikan pada khalayak dapat langsung diterima oleh khalayak itu sendiri. Tidak mengenal jarak karena jangkauan televisi umumnya tidak terbatas kecuali adanya faktor alam yang mempengaruhi teknis seperti daerah yang bergunung-gunung. Perkembangan dunia pertelivisian di Indonesia tersebut tidak lepas dari perkembangan media global, bahwa perkembangan media global akan membawa pengaruh yang tidak kecil terhadap media nasional suatu negara. Hal ini tentu menjadi sebuah keniscayaan mengingat media nasional juga merupakan bagian dari media global tersebut. Walaupun tidak dapat dipungkiri bahwa seringkali kiblat dari media global ini adalah negara-negara barat yang menjadi pencetus pengembangan teknologi informasi dan komunikasi.

Jika media global memiliki nilai dan pengaruh dari negara barat yang dominan maka tak dapat dihindari pula pengaruhnya terhadap pemirsanya. Globalisasi media yang semakin memudahkan insersi nilai-nilai pembuatnya (negara barat). Dengan semakin mudahnya nilai tersebut untuk masuk ke dalam televisi telah menjadi bagian dalam kehidupan masyarakat. Namun dalam sebuah ruang keluarga, televisi telah menjadi pusat komunikasi dan bersantai antara ayah sepulang bekerja, ibu selesai berbenah dan anak sepulang beraktifitas. Namun ada beberapa keluarga, yang anaknya diberikan kebebasan dengan memberikan televisi di dalam kamar pribadinya, sehingga pengawasan serta pembimbingan dalam menonton televisi menjadi hilang. Anak-anak sangat rentan terhadap siaran yang tidak sehat, 
dikarenakan sifat anak yang lebih adaptif dan tidak selektif dalam melihat siaran-siaran di televisi.

Berdasarkan data survei nielsen di jakarta dan sekitarnya, pada kwartal ke-3 tahun 2012 terhadap 25.072.000 individu, usia 10 tahun keatas, diketahui bahwa kegemaran populasi secara umum adalah sebagai berikut : olah raga (47\%), menonton televisi (38\%), mendengar musik (24\%), memasak (19\%), dan membaca Al-Qur'an (12\%). Hal ini dipertegas dengan penelitian yang menyebutkan bahwa lama menonton televisi adalah 3-5 jam per hari untuk semua kategori umur dan 5 jam sehari untuk anak-anak di bawah 10 Tahun, Jadi tidak heran jika akhirnya anak-anak akan tumbuh dengan gaya hidup "ala televisi". Tayangan kartun berupa adegan kekerasan, misalnya akan masuk ke dalam alam bawah sadar anak bahwa adegan tersebut adalah perilaku yang lazim. Pada akhirnya tingkat sensitivitas anak akan menjadi berkurang, karena secara terus-menerus diterpa oleh tayangan kekerasan (Riyanto, R.M :2013).

Khusus di makassar, ada sebuah fakta yang mencemaskan, bila kita melihat lamanya anak-anak menonton televisi. Survei yang dilakukan KPID Sulsel terhadap 1000 anak di makassar, tahun 2005, memperkuat kesimpulan begitu kuatnya pengaruh televisi terhadap anak. Survei terhadap anak usia 6-10 tahun, yang masih duduk di bangku kelas 1 sampai 3 SD itu menunjukan bahwa begitu pulang sekolah, sebagian besar (78\%) langsung duduk di depan televisi (antara pukul 10.00 - 13.00). selebihnya mengaku tidak melakukan aktivitas menonton rutin, tapi lebih banyak menonton televisi dari pada keluar rumah. Begitu sore tiba (pukul 16.00 - 18.00), sebanyak 83\% anak kembali melanjutkan menonton televisi, ada malam hari (20.00-22.00), jumlah anak yang menonton televisi tetap banyak, yakni mencapai $74 \%$.

Survei ini menyimpulkan, lebih dari 70\% anak di Makassar menonton televisi selama 7 jam sehari rata-rata 2.100 jam sebulan. Padahal waktu yang dibutuhkan untuk belajar disekolah 900 jam sebulan. Kesimpulan ini mengindikasikan, banyak anak menonton acaraacara televisi yang yang bukan ditujukan untuk mereka. Survei ini sejalan dengan hasil penelitian yang menunjukan bahwa acara anak-anak diseluruh televisi swasta hanya 32 jam, sementara kebiasaan anak anak-anak indonesia menonton selama 68 jam dalam sepekan. Ini berarti selama 36 jam anak-anak menonton acara televisi yang pantas ditonton orang dewasa. 
(Rusdin Tompo, dalam panorama penyiaran di Sulawesi Selatan:2010). Pengetahuan masyarakat terhadap isi siaran juga tergolong masih minim, anggapan mereka yang penting menghibur, apakah hiburan tersebut mendidik ataupun tidak hal ini juga menjadi masalah, pemahaman terhadap klasifikasi program siaran masih sangat kurang bahkan sering terabaikan, anak-anak dibiarkan menonton yang bukan menjadi tontonannya.

Lembaga Penyiaran khususnya Televisi, sangat kompetitif dalam hal program siaran, disebabkan aspek bisnis/ Komersil yaitu perolehan iklan serta orientasi terhadap rating. Dua hal tersebut yang terkadang membuat Lembaga Televisi tidak segan-segan menampilkan tayangan yang tidak mendidik dalam program tayangannya, misal saja kultur kekerasan, yang ditayangkan tanpa mengenal waktu (Primetime), seperti tayangan demonstrasi serta kekerasan lain. Komisi Penyiaran Indonesia Daerah Sulawesi Selatan (KPID Sulsel), merupakan stakeholder yang mengatur penyiaran, khususnya di wilayah Sulawesi Selatan. Berdasarkan Undang-undang 32 Tahun 2002 Pasal 8 ayat (2), secara garis besar KPI memiliki tiga fungsi antara lain fungsi regulasi, pelayanan pada masyarakat serta pengawasan dan pengenaan sanksi.

Televisi Lokal memiliki andil besar dalam kemajuan penyiaran di Sulawesi Selatan, khususnya di Kota Makassar, yang menjadi salah satu wilayah layanan ke enam televisi tersebut, siaran serta program yang disajikan tidak lepas dari nuansa budaya lokal serta informasi seputar wilayah Sulawesi Selatan. Televisi lokal khususnya lembaga penyiaran swasta lokal, dalam proses siarannya juga sering melakukan pelanggaran. KPID Sulsel sering mengeluarkan "Surat Cinta" atau Surat Teguran ke Televisi yang melakukan pelanggaran tersebut untuk diklarifikasi, namun terkadang televisi yang melanggar tidak merespon positif teguran KPID Sulsel, dan pelanggaran isi siaran sering dilakukan berulangulang tanpa mengindahkan aturan yang berlaku.

Tujuan dari peneitian ini adalah untuk mengetahui bagaimana KPID Sulsel melakukan pengawasan, pembinaan serta kebijakan komunikasi terhadap pelanggaran isi siaran oleh televisi lokal. 


\section{B. BAHAN DAN METODE}

\section{Desain Penelitian}

Penelitian ini didesain secara deskriptif dengan menggunakan metode penelitian kualitatif yang dimaksudkan untuk melukiskan secara sistematis dan akurat fakta-fakta, menginterpretasi dan menganalisis mengenai Pelanggaran yang dilakukan Televisi Lokal dan Pemberian Sanksi oleh KPID Sulawesi Selatan. Penelitian kualitatif pada pelaksanaannya tidak harus menggunakan subyek atau obyek yang besar, tetapi memerlukan deskripsi secara mendalam dan komperhensif, sehingga mampu memberikan gambaran secara luas, kaya dan hidup. Oleh karena itu penelitian kualitatif juga digunakan untuk sekala kecil dan bersifat kasus dengan menekankan pada proses alami dengan deskripsi yang intensif dalam setiap langkkahnya. Jadi ciri penelitian kulitatif yaitu "thick description" lukisan mendalam terhadap obyek penelitian.

\section{Metode Pengumpulan Data}

Obyek penelitian dalam hal ini adalah informan. Menurut Bungin (2008:76-77), informan penelitian adalah subyek yang memahami informasi obyek penelitian sebagai pelaku maupun orang lain yang memahami obyek penelitian. Adapun informan dalam penelitian ini dipilih, dimulai dengan menetapkan secara purposive, yakni Ketua KPID Sulawesi Selatan, Wakil Ketua KPID Sulawesi Selatan, Koordinator bidang pengawasan isi siaran (monitoring), kemudian atas rekomendasi mereka diteruskan dengan teknik bola salju (snow ball) untuk mencari informan lainnya kepada Tim Monitoring yang bertugas disekretariat KPID Sulawesi Selatan dan mencocokan dengan keterangan dari penanggungjawab siaran beberapa lembaga penyiaran televisi lokal ( TVRI Sulsel, Kompas TV Makassar, Fajar TV, Celebes TV, I News TV yang sebelumya bernama SUN TV dan Ve Channel). Korpus dalam hal ini adalah hasil wawancara dengan para informan guna mensinkronkan data-data dari keterangan komisioner KPID Sulsel, tim monitoring dan penanggungjawab siaran televisi lokal.

\section{Metode Analisis Data}


Penelitian ini adalah penelitian pelanggaran siaran televisi lokal dan pemberian sanksi oleh KPID Sulsel, peneliti menganalisis seberapa besar jumlah atau banyaknya pelanggaran yang dilakukan oleh lembaga penyiaran khususnya televisi lokal yang ada di makassar dengan menggunakan tabel frekuensi serta hubungannya dengan pemberian sanksi oleh KPID Sulsel dan strategi kebijakan apa yang dikeluarkan KPID Sulsel. Setiap data yang telah dikumpulkan dianalisis dengan metode analisis kualitatif, dengan teknik analisis kebijakan komunikasi. Evaluasi dari Kebijakan Komunikasi pada proses pemberian sanksi oleh KPID Sulawesi Selatan dalam rangka memperbaiki tatakelola pengawasan isi siaran serta meminimalisir pelanggaran guna pemberian pelayanan yang optimal dalam hal siaran kepada masyarakat di kota makassar.

\section{HASIL}

\section{Dominasi pelangaran yang didapatkan dari hasil monitoring KPID Sulsel.}

Lembaga penyiaran televisi lokal yang melakukan pelanggaran isi siaran berdasarkan Peraturan KPI Nomor 01/P/KPI/03/2012 tentang Pedoman Perilaku Penyiaran dan Nomor 02/P/KPI/03/2012 tentan Standar Program Siaran, selama periode tahun 2014 sampai dengan 2015. Dari dua kategori pelanggaran yang paling banyak dan menjadi objek dari peneilitian ini adalah Penggolongan program siaran dan siaran iklan seperti dijelaskan pada tabel 1 dan 2: yang menerangkan bahwa televisi lokal di kota makassar belum mematuhi aturan P3SPS sebagaimana mestinya. Kendala dari permasalahan ini adalah lembaga penyiaran menganggap "sepele" pelanggaran penggolongan program siaran, dan KPID Sulsel tidak melakukan penindakan yang tegas terhadap pelanggaran ini, karena selain masuk dalam kategori pelanggaran ringan, komisioner merasa harus adil (tidak tebang pilih) dalam memberikan sanksi, mengingat televisi nasional yang berjaringan (SSJ) masih ada yang juga melakukan pelanggaran penggolongan program siaran.

Pelanggaran terbesar ke dua adalah siaran iklan dengan pelanggaran bloking time dan iklan superlatif. Pelanggaran tersebut terjadi karena minimnya pemahaman aturan Pedoman Perilaku Penyiaran dan Standar Program Siaran (P3SPS) selain itu minimnya pengiklan yang mau beriklan di televisi lokal, sehingga iklan yang dikemas dalam bentuk program home 
shoping menjadi siaran yang mengisi sebagian besar program siaran televisi lokal serta kebijakan gorup perusahaan yang menerima paket iklan tersebut. Sedangkan untuk iklan superlatif murni karena kurangnya pemahaman P3SPS. Tabel 3 menjelaskan jumlah pelanggaran yang didapatkan. Pelanggaran tersebut jika dibandingkan dengan sanksi yang diberikan tidak berbanding lurus dengan jumlah yang seharusnya, hal ini menjadi temuan dalam penelitian.

\section{Pengelolaan sanksi KPID Sulsel}

P3SPS yang merupakan hasil kesepakatan seluruh KPI/ KPI Daerah se Indonesia yang ditetapkan dalam Peraturan KPI sebagai pedoman bagi lembaga penyiaran dalam melakukan penyelenggaraan penyiaran yang sudah mengalami 2 kali perubahan pertama di tahun 2009 dan kedua tahun 2012. Berdasarkan peraturan KPI Nomor 02/P/KPI/03/2012 tentang Standar Program Siaran jelas mengatur tentang bagaimana KPI dalam menjatuhkan sanksi. Berdasarkan Rekapitulasi Permintaan Klarifikasi, Permintaan Penghentian Siaran Iklan, Tanggapan dan Teguran Tertulis untuk Tahun 2014 sampai dengan 2015, jelas bahwa KPID sangat minim memberikan sanksi jika dibandingkan pelanggaran yang terjadi. Sanksi yang paling berat keluarkan oleh KPID Sulsel adalah sanksi administratif yakni teguran tertulis.

\section{Strategi Kebijakan yang dikeluarkan oleh KPID Sulsel}

Komisi Penyiaran Indonesia Daerah Sulawesi Selatan dalam melakukan strategi kebijakannya didukung oleh sekretariat dalam menyusun program kegiatan. Strategi kebijakan guna meminimalisir pelanggaran dan meningkatkan penyiaran yang sehat bagi masyarakat khususnya di wilayah Sulawesi Selatan yang dikemas dalam beberapa program kegiatan baik yang termasuk dalam Pengawasan, Pembinaan hingga pemberian apresiasi (Reward). Program kegiatan tersebut antara lain : Forum Masyarakat Peduli Penyiaran Sehat (FMPPS) yang merupakan salah satu program strategis Komisi Penyiaran Indonesia Daerah Sulawesi Selatan dalam memberdayakan masyarakat untuk menjadi "mata dan telinga" KPID di Kabupaten/ Kota se Sulawesi Selatan.

Program lain yang diselenggarakan KPID Sulsel setiap tahunnya adalah Anugerah KPID Award yang menjadi icon lembaga ini. Pentingnnya peningkatan kualitas isi siaran, 
mengingat isi siaran merupakan cermin sekaligus tolak ukur penilaian kemampuan sumber daya manusia lembaga penyiaran bersangkutan. Lewat isi siaranlah kita bukan hanya akan melihat ragam kreatifitas insan penyiaran tapi juga dapat membaca sejauh mana mereka menimbang dampak luas sebuah siaran terhadap masyarakat, terutama khalayak khusus, yakni anak-anak, remaja, dan perempuan. Hal ini penting digarisbawahi karena dampak siaran bisa memberi warna pada perilaku, nilai, sikap dan gaya hidup seseorang atau masyarakat, bahkan memiliki kekuatan dalam pembentukan opini yang memengaruhi sebuah kebijakan publik.

Program yang mengusung Gerakan Menonton Sehat merupakan salah satu strategi KPID sebagai representasi publik yang menginginkan agar stasiun televisi senantiasa menyajikan tayangan yang sesuai dengan fungsi media elektronik sesuai yang tercantum di dalam Undang-undang 32 Tahun 2002 tentang penyiaran yaitu sebagai media informasi, media hiburan media pendidikan serta perekat sosial. Kenyataannya media televisi saat ini tidak sepenuhnya dapat mengikuti amanah Undang-undang tersebut. Untuk itu KPID Sulsel berinisiatif untuk mengubah strategi dengan menguatkan posisi masyarakat sebagai konsumen. KPID Sulsel merangkul LSM, para guru, siswa, dan kelompok-kelompok masyarakat untuk bersama-sama melakukan perlawanan terhadap tayangan televisi yang tidak mendidik. KPID Sulsel untuk mendukung gerakan ini telah mengeluarkan beberapa Buku literatur terkait Panduan menonton sehat, antara lain Panduan Praktis Menonton Sehat untuk Orang Tua (2007) dan Panduan Praktis Menonton Sehat untuk Anak (2007).

Wacana tentang perlunya memperbaiki kualitas isi siaran melalui peningkatan kualitas SDM penyiaran mengemuka sejak rapat kerja pertama KPID Sulsel periode 20072010. Pada saat itu dipikirkan agar pendekatan penjatuhan sanksi atau penghukuman atas pelanggaran isi siaran perlu dibarengi dengan upaya pemulihan ruang publik yang sudah tercederai melalui pengembangan kapasitas SDM penyiaran yang sistematis. Itu berarti, KPID Sulsel tidak semata-mata melakukan pendekatan punishment terhadap pelanggaran isi siaran yang sudah terjadi, tapi juga berupaya mencari solusi kreatif jangka panjang yang bersifat antisipatif dan strategis.

\section{PEMBAHASAN}


Penelitian ini menemukan beberapa hal penting terkait pelanggaran siaran yang sering terjadi pada televisi lokal di wilayah layanan kota makassar, bagaimana KPID Sulsel dalam mengelola sanksi atas pelanggaran yang sering terjadi dan berulang-ulang serta kebijakan yang dikeluarkan oleh Komisioner KPID Sulsel Periode 2014-2017 dalam meminimalisir pelanggaran yang sering terjadi.

Berdasarkan hasil penelitian dominasi pelanggaran siaran televisi lokal pertama yang paling banyak adalah pelanggaran penggolongan program siaran dan yang kedua adalah siaran iklan. Pelanggaran ini dapat diklasifikasikan dalam beberapa jenis dan jenis pelanggaran yang paling banyak di tahun 2014 adalah penggolongan program siaran dan Lembaga Penyiaran Publik TVRI Sulawesi Selatan merupakan yang memiliki pelanggaran terbanyak dan kedua terbanyak dimiliki oleh Lembaga Penyiaran Swasta Lokal Kompas TV Makassar. TVRI Sulawesi Selatan yang memiliki jadwal siaran lokal hanya di jam 16.00 wita sampai dengan 20.00 wita dan selebihnya adalah relay siaran TVRI Pusat. Pelanggaran penggolongan program siaran bukan saja terjadi pada siaran lokal TVRI Sulawesi Selatan saja namun tingkat pusat juga tidak mencantumkan kategori atau penggolongan dimaksud.

Pelanggaran yang paling banyak di tahun 2015 adalah penggolongan program siaran dan Lembaga Penyiaran Swasta Lokal INews TV merupakan yang memiliki pelanggaran terbanyak, dan kedua terbanyak dimiliki oleh Lembaga Penyiaran Publik TVRI Sulawesi Selatan. Mirisnya ditahun 2014 dengan label SUN TV dan SINDO TV pelanggaran penggolongan siaran jauh lebih rendah dibanding pada tahun 2015 dengan logo dan manajemen baru memiliki pelanggaran penggolongan siaran yang meningkat drastis. Hal ini menandakan tidak patuhnya/ tidak sensitifnya manajemen induk siaran terhadap aturan P3SPS, begitu juga dengan TVRI Sulawesi Selatan yang seharusnya menjadi model percontohan bagi televisi swasta, tidak ditindak tegas oleh KPID Sulsel selaku regulator. Hal ini menandakan bahwa Komisioner KPID Sulawesi selatan tidak melakukan penegakan aturan/ tidak melaksanakan fungsinya dengan baik sebagai pembuat kebijakan.

Mekanisme Alur Penjatuhan Sanksi oleh KPID Sulsel yang terjadi jika ditelusuri, diawali dengan pencatatan dugaan pelanggaran P3SPS pada hasil monitoring dari 10 tenaga monitoring yang kemudian dilakukan analisis pelanggaran oleh 1 orang dari 10 tenaga monitoring (merangkap), kemudian hasil analisis dilakukan perekapan oleh staf monitoring 
lalu dikirim ke email masing-masing komisioner untuk dianalisis akhir untuk diplenokan. Namun komisioner hanya melakukan pleno pada pelanggaran yang menurutnya berat seperti tayangan muatan seksual, dan untuk pelanggaran penggolongan program siaran masuk dalam kategori ringan, sehingga tidak ada tindaklanjut (No Action) atas pelanggaran penggolongan program siaran, setelah itu komisioner KPID bersurat untuk meminta klarifikasi dari lembaga penyiaran yang melakukan pelanggaran, selanjutnya dilakukan sidang pemeriksaan yang dituangkan dalam berita acara, namun dalam pelaksanannya KPID Sulsel hanya melalui notulensi sebagai dokumen pemeriksaan.

Berdasarkan P3SPS alur Monitoring yang ideal dan seharusnya dilakukan oleh KPID Sulsel adalah seperti dalam (gambar 1). Pembiaran ini juga menjadi sebuah dilema bagi komisioner, jika dilakukan penindakkan maka hampir seluruh lembaga penyiaran televisi lokal yang menjadi pantauan KPID Sulsel akan terkena sanksi, sedangkan masih banyak siaran televisi nasional/ siaran berjaringan yang tidak menampilkan penggolongan program siaran. Perhatian Komisioner terhadap penyelenggaraan monitoring juga menjadi perhatian, karena banyak keluhan dari tim monitoring bahwa tidak adanya perhatian khusus terhadap tim monitoring.

Kebijakan yang pernah dikeluarkan oleh KPID terkait pelanggaran penggolongan program siaran adalah dengan memberikan kelonggaran bagi lembaga penyiaran untuk meletakkan penggolongan program siaran di mana saja (tidak harus di pojok kanan atas) mengingat banyak masukan dari lembaga penyiaran bahwa pojok kanan atas akan mengganggu ID station / lambang dari TV yang bersangkutan. Kebijakan ini hanya dilakukan berdasarkan hasil pleno komisioner yang didokumentasikan dengan hasil notulen, dan kebijakan ini sifatnya lebih kedalam (internal KPID Sulsel) dalam memonitoring isi siaran. Kebijakan yang dikeluarkan oleh KPID Sulsel tidak menggunakan kaidah-kaidah tahapan penyusunan kebijakan seperti yang dijelaskan berdasarkan Teori Kebijakan Publik, bahwa Kebijakan harus melalui proses: (1) Fase penyusunan Agenda; (2) Fase Formulasi Kebijakan; (3) Fase Adopsi Kebijakan; (4) Fase Implementasi Kebijakan; dan (5) Fase Penilaian Kebijakan. Dunn, (2003). Selain itu Strategi Kebijakan KPID dalam meminimalisir pelanggaran serta meningkatkan kualitas isi siaran, dengan membuat program-program kegiatan untuk mendukung hal tersebut. 
Program Forum Masyarakat Peduli Penyiaran Sehat (FMPPS) di KPID Sulsel merupakan program pemberdayaan partisipasi masyarakat dalam penyiaran sehat di 24 Kabupaten/ Kota se Sulawesi Selatan, yang tidak mungkin dijangkau oleh KPID Sulsel untuk pengawasannya. Kendala/ masalah yang terjadi pada program ini adalah minimnya serta tidak adanya alokasi anggaran KPID Sulsel untuk kesinambungan/ keberlangsungan FMPPS yang terbentuk di daerah-daerah. Dan sebagai solusinya Forum MPPS dianggarkan di Pemerintah kabupaten/ kota di Sulawesi Selatan melalui Peraturan Daerah atau Peraturan Walikota. Program ini juga memiliki kendala minimnya laporan forum yang telah terbentuk, serta minimnya peningkatan kapasitas pengetahuan bagi pengurus dan anggota Forum tersebut.

Program lain yang tidak kalah pentingnya adalag Gerakan Produksi Sehat (GESIT) dan Gerakan Menonton Sehat (GEMES). Kedua gerakan ini memiliki semangat yang sama yaitu menciptakan iklim siaran yang sehat, namun memiliki obyek yang berbeda. GESIT yang dijadikan obyek adalah lembaga penyiaran yang memproduksi siaran, sedangkan GEMES adalah masyarakat yang mengkonsumsi siaran. Program GESIT yang sering dilakukan oleh KPID belum optimal, sesungguhnya gerakan ini dapat dikembangkan lebih dengan menggandeng institusi atau perguruan tinggi baik negeri maupun swasta untuk membuat Sekolah P3SPS serta Sertifikasi dan Standarisasi SDM Penyiaran. Program unggulan KPID Sulsel yang lain adalah Penganugerahan (Award) kepada lembaga serta insan penyiaran atas kreatifitas dalam mendukung penyiaran sehat pada Program KPID Award. Program ini masih perlu ditingkatkan partisipasinya khususnya keterlibatan lembaga penyiaran untuk berkompetisi menjadi yang terbaik.

Kebijakan-kebijakan yang dikelurkan oleh KPID Sulsel tidak lepas dari kewenangan yang diberikan oleh undang-undang untuk mengimplementasikan kebijakan, khususnya terkait dengan kelembagaan dimana KPI Daerah yang saat ini memiliki sifat koordinatif dengan KPI Pusat juga merupakan kendala bagi proses penjatuhan sanksi, artinya tidak ada intervensi KPI Pusat dalam proses kebijakan yang dikeluarkan KPID Sulsel. Sebagai solusinya, harus dilakukan revisi undang-undang yang menyatakan bahwa KPI dan KPI daerah memiliki hubungan yang bersifat struktural, hal ini akan berdampak siginifikan terhadap pemberian kebijakan. Pada internal masing-masing KPI baik pusat maupun daerah, 
komisionernya memiliki hubungan yang sifatnya kolektif kolegial (kedudukan dan porsi yang sama pada masing-masing komisioner) sehingga rentan terjadinya konflik dan perbedaan pandangan. Dan untuk pengawasan kerja masing-masing komisioner hanya pada DPRD Provinsi yang dituangkan dalam bentuk laporan bulanan komisioner khususnya di KPI Daerah Sulawesi Selatan. Akan menjadi lebih efektif jika KPI/ KPI Daerah memiliki dewan pengawas, sebagai wadah mediasi jika terjadi konflik antar komisioner serta kontrol dari pelaksanaan tugas, pokok dan fungsi dari masing-masing komisioner.

Revisi undang-undang menjadi sangat penting, khusunya pada kewenangan KPI/ KPI Daerah dalam menjatuhkan sanksi pada lembaga penyiaran yang melanggar P3SPS.. Begitu juga revisi P3SPS juga dibutuhkan mengingat belum tuntasnya definisi-definisi seperti kategori pelanggaran (ringan, sedang dan berat). Selain itu sosialisasi P3SPS harus lebih intens dilakukan guna meningkatkan pemahaman terhadap aturan tersebut.

\section{E. KESIMPULAN DAN SARAN}

Kami menyimpulkan bahwa pelanggaran yang sering terjadi pada televisi lokal adalah karena ketidakpahaman SDM penyiaran terhadap aturan P3SPS, serta menganggap "sepele" pelanggaran penggolongan program siaran dibuktikan pada (Gambar 2). Upaya meminimalisisr pelanggaran terus dilakukan antara lain dengan memberikan kebijaksanaan terhadap mekanisme penggolongan program siaran serta melakukan berbagai program kegaiatan yang lebih terukur dan terarah seperti Sosialisasi P3SPS, Pembentukan dan Pembinaan FMPPS, KPID Award, Workshop Penyiaran, GESIT, GEMES, FGD, Literasi Media, Sekolah P3SPS, bahkan perlu melakukan revisi beberapa aturan perundangundangan, seperti UU 32 Tahun 2002 untuk memperkuat kewenangan KPI/KPI Daerah, P3SPS untuk menuntaskan pemahaman pelanggaran. 


\section{DAFTAR PUSTAKA}

Anshar M. A A. 2009. Standarisasi Manajemen Penyiaran : Mewujudkan Profesionalisme Radio \& TV. Cetakan Pertama. PT. Umitoha Ukhuwah Grafika. Makassar.

Bungin, B, 2008, Penelitian Kualitatif, Jakarta: Putra Grafika.

Dunn, W. N. 2003. Analisis Kebijakan Publik. Yogyakarta: PT Hanindita Graya Widya.

Hafied, C. 2013, Perencanaan dan Strategi Komunikasi, Ed. 1 Cetakan ke-1. Rajawali Pers. Jakarta.

, 2014, Pengantar Ilmu Komunikasi, Ed.2 Cetakan Ke-14, Rajawali Pers. Jakrata.

Ishadi, SK. 2014. Media dan Kekuasaan : Televisi di Harih-hari Terakhir Presiden Soeharto. PT Kompas Media Nusantara. Jakarta.

Komisi Penyiaran Indonesia Daerah Sulawesi Selatan, 2010, Panorama Penyiaran di Sulawesi Selatan, PT. Umitoha Ukhuwah Grafika. Makassar

McQuail, D. 2011. Teori Komunikasi Massa McQuail. (Terjemahan) Ed.6 Buku 1. Salemba Humanika. Jakarta.

, 2011. Teori Komunikasi Massa McQuail. (Terjemahan) Ed.6 Buku 2. Salemba Humanika. Jakarta.

Riyanto, R. M. 2013. Kekerasan di Layar Kaca : Bisnis Siaran, Peran KPI dan Hukum. PT. Kompas Media Nusantara. Jakarta.

Syahputra, I. 2013. Rezim Media : Pergulatan Demokrasi, Jurnalisme dan Infotainment dalam Industri Televisi. Cetakan Pertama. PT. Gramedia. Jakarta.

Williams, R. 2009. Televisi Cetakan Pertama. Resist Book. Yogyakarta.

Wiryawan, H. 2007. Dasar-dasar Hukum Media. Cetakan 1. Pustaka Pelajar. Yogyakarta. 
LAMPIRAN

Tabel 1. Rekapitulasi Dugaan Pelanggaran Siaran Televisi Lokal Tahun 2014 REKAPITULASI DUGAAN PELANGGARAN SIARAN TELEVISI LOKAL TAHUN 2014

\begin{tabular}{|c|c|c|c|c|c|c|c|c|c|c|c|c|c|c|c|c|c|c|c|c|}
\hline \multirow{2}{*}{ LEMBAGA PENYIARAN } & \multicolumn{20}{|c|}{ DUGAAN PELANGGARAN BERDASARKAN ATURAN P3SPS } \\
\hline & A & B & C & D & E & $\mathrm{F}$ & G & $\mathrm{H}$ & 1 & $\mathrm{~J}$ & $\mathrm{~K}$ & $\mathrm{~L}$ & M & $\mathrm{N}$ & 0 & $\mathbf{P}$ & Q & $\mathrm{R}$ & $S$ & $\mathrm{~T}$ \\
\hline TVRI SULSEL & 4615 & 122 & 36 & 55 & 0 & 4 & 2 & 6 & 0 & 46 & 8 & 3 & 1 & 5 & 0 & 0 & 1 & 0 & 0 & 1 \\
\hline FAJAR TV & 2780 & 332 & 176 & 141 & 2 & 35 & 16 & 16 & 58 & 147 & 23 & 4 & 7 & 2 & 0 & 2 & 12 & 10 & 0 & 2 \\
\hline CELEBES TV & 3829 & 706 & 293 & 120 & 84 & 29 & 27 & 18 & 18 & 8 & 7 & 5 & 1 & 1 & 0 & 0 & 0 & 0 & 0 & 0 \\
\hline KOMPAS TV MAKASSAR & 4456 & 314 & 128 & 336 & 1 & 29 & 22 & 42 & 2 & 141 & 38 & 12 & 1 & 21 & 0 & 1 & 8 & 5 & 2 & 2 \\
\hline iNEWS TV & 1596 & 60 & 92 & 23 & 1 & 17 & 0 & 79 & 0 & 23 & 78 & 0 & 8 & 0 & 6 & 1 & 0 & 0 & 0 & 0 \\
\hline VE CHANNEL & 116 & 2 & 0 & 0 & 2 & 0 & 0 & 0 & 1 & 0 & 0 & 0 & 0 & 0 & 0 & 0 & 0 & 0 & 0 & 0 \\
\hline TOTAL & 17392 & 1536 & 725 & 675 & 90 & 114 & 67 & 161 & 79 & 365 & 154 & 24 & 18 & 29 & 6 & 4 & 21 & 15 & 2 & 5 \\
\hline
\end{tabular}

Tabel 2. Rekapitulasi Dugaan Pelanggaran Siaran Televisi Lokal Tahun 2015

\section{REKAPITULASI DUGAAN PELANGGARAN SIARAN TELEVISI LOKAL TAHUN 2015}

\begin{tabular}{|c|c|c|c|c|c|c|c|c|c|c|c|c|c|c|c|c|c|c|c|c|c|}
\hline \multirow{2}{*}{\multicolumn{2}{|c|}{ LEMBAGA PENYIARAN }} & \multicolumn{20}{|c|}{ DUGAAN PELANGGARAN BERDASARKAN ATURAN P3SPS } \\
\hline & & $A$ & B & C & D & $\mathbf{E}$ & $\mathbf{F}$ & G & $\mathrm{H}$ & I & $\mathrm{J}$ & K & $\mathbf{L}$ & M & $\mathrm{N}$ & 0 & P & Q & $\mathbf{R}$ & $S$ & $T$ \\
\hline \multicolumn{2}{|c|}{ TVRI SULSEL } & 3120 & 3 & 0 & 1 & 0 & 0 & 0 & 0 & 0 & 0 & 0 & 0 & 0 & 0 & 0 & 0 & 0 & 0 & 0 & 0 \\
\hline \multicolumn{2}{|c|}{ FAJAR TV } & 499 & 0 & 0 & 0 & 2 & 0 & 0 & 0 & 0 & 0 & 3 & 0 & 0 & 0 & 0 & 0 & 0 & 0 & 0 & 0 \\
\hline \multicolumn{2}{|c|}{ CELEBES TV } & 3036 & 271 & 0 & 0 & 0 & 0 & 4 & 58 & 70 & 0 & 1 & 0 & 2 & 0 & 2 & 0 & 2 & 0 & 0 & 0 \\
\hline \multicolumn{2}{|c|}{ KOMPAS TV MAKASSAR } & 3049 & 201 & 0 & 74 & 0 & 0 & 0 & 3 & 2 & 0 & 1 & 0 & 0 & 0 & 0 & 0 & 0 & 0 & 0 & 0 \\
\hline \multicolumn{2}{|c|}{ i NEWS TV } & 3799 & 53 & 0 & 6 & 0 & 0 & 1 & 1 & 1 & 0 & 0 & 0 & 1 & 0 & 58 & 0 & 0 & 0 & 0 & 0 \\
\hline \multicolumn{2}{|c|}{ VE CHANNEL } & 1803 & 141 & 0 & 0 & 0 & 0 & 0 & 86 & 109 & 0 & 0 & 0 & 1 & 0 & 0 & 0 & 0 & 0 & 0 & 0 \\
\hline \multicolumn{2}{|c|}{ TOTAL } & 15306 & 669 & 0 & 81 & 2 & 0 & 5 & 148 & 182 & 0 & 5 & 0 & 4 & 0 & 60 & 0 & 2 & 0 & 0 & 0 \\
\hline \multicolumn{22}{|c|}{ KETERANGAN } \\
\hline \multirow{2}{*}{ A } & \multicolumn{4}{|c|}{ Penggolongan program siaran } & \begin{tabular}{l|l}
$\mathrm{F}$ & $\mathrm{F}$ \\
\end{tabular} & \multicolumn{4}{|c|}{ Program siaran jurnalistik } & $\mathrm{K}$ & \multicolumn{5}{|c|}{ Muatan seksualitas } & $P$ & \multicolumn{5}{|c|}{ Pelarangan adegan seksualitas } \\
\hline & \multicolumn{4}{|l|}{ Siaran Iklan } & $\mathrm{G}$ & \multicolumn{5}{|c|}{ Muatan kekerasan dan sadisme } & \multicolumn{5}{|c|}{ Hak siar } & Q & \multicolumn{5}{|c|}{$\begin{array}{l}\text { Perlindungan kepada orang dan } \\
\text { kelompok masyarakat tertentu }\end{array}$} \\
\hline C & \multicolumn{4}{|c|}{$\begin{array}{l}\text { Siaran Pemilihan Umum dan } \\
\text { Pemilihan Umum Kepala Daerah }\end{array}$} & $\mathrm{H}$ & \multicolumn{4}{|c|}{$\begin{array}{l}\text { Nilai dan Norma kesopanan \& } \\
\text { kesusilaan }\end{array}$} & M & \multicolumn{5}{|c|}{$\begin{array}{l}\text { Perlindungan kepada anak } \\
\text { dan/atau remaja }\end{array}$} & $\mathrm{R}$ & \multicolumn{5}{|c|}{ Running Text } \\
\hline D & \multicolumn{4}{|c|}{ Iklan klinik kesehatan } & I & \multicolumn{4}{|c|}{$\begin{array}{l}\text { Muatan seks dalam lagu dan } \\
\text { video klip }\end{array}$} & $\mathrm{N}$ & \multicolumn{5}{|c|}{ Sensor } & $\mathrm{S}$ & \multicolumn{5}{|c|}{ Peliputan Bencana } \\
\hline $\mathrm{E}$ & \multicolumn{4}{|c|}{$\begin{array}{l}\text { Larangan dan pembatasan muatan } \\
\text { rokok, NAPZA (Narkotika, } \\
\text { Psikotropika dan Zat Aditif) dan } \\
\text { minuman beralkohol }\end{array}$} & J & \multicolumn{4}{|c|}{$\begin{array}{l}\text { Perlindungan kepentingan } \\
\text { publik }\end{array}$} & 0 & Bloc & ing $T$ & & & & $\mathrm{~T}$ & $\begin{array}{l}\text { Peng } \\
\text { Profe }\end{array}$ & orma & & & \\
\hline
\end{tabular}

Tabel 3. Tabel Rekapitulasi Permintaan Klarifikasi, Permintaan Penghentian Siaran Iklan, Tanggapan dan Teguran Tertulis Tahun 2014 dan 2015

\begin{tabular}{lcccccc}
\hline & \multicolumn{5}{c}{ Jenis Sanksi dan Tanggapan } \\
Lembaga Penyiaran & $\begin{array}{c}\text { Tahun 2014 } \\
\text { Permintaan } \\
\text { Klarifikasi }\end{array}$ & $\begin{array}{c}\text { Penghentian } \\
\text { siaran iklan }\end{array}$ & Tanggapan & $\begin{array}{c}\text { Permintaan } \\
\text { Klarifikasi }\end{array}$ & $\begin{array}{c}\text { Tahun 2015 } \\
\text { Penghentian } \\
\text { siaran iklan }\end{array}$ & Tanggapan \\
\hline LPP TVRI & 4 & 1 & 1 & 4 & 1 & 1 \\
Fajar TV & 5 & 1 & 0 & 5 & 1 & 0 \\
Celebes TV & 2 & 1 & 0 & 2 & 1 & 0 \\
\hline
\end{tabular}




\begin{tabular}{lllllll}
\hline Kompas TV Makassar & 2 & 1 & 0 & 2 & 1 & 0 \\
I News TV & 1 & 3 & 0 & 1 & 3 & 0 \\
VeChannel & 0 & 0 & 0 & 0 & 0 & 0 \\
\hline
\end{tabular}

Sumber : KPID Sulsel (2016)

Gambar 1. Mekanisme Penjatuhan Sanksi Berdasarkan P3SPS.

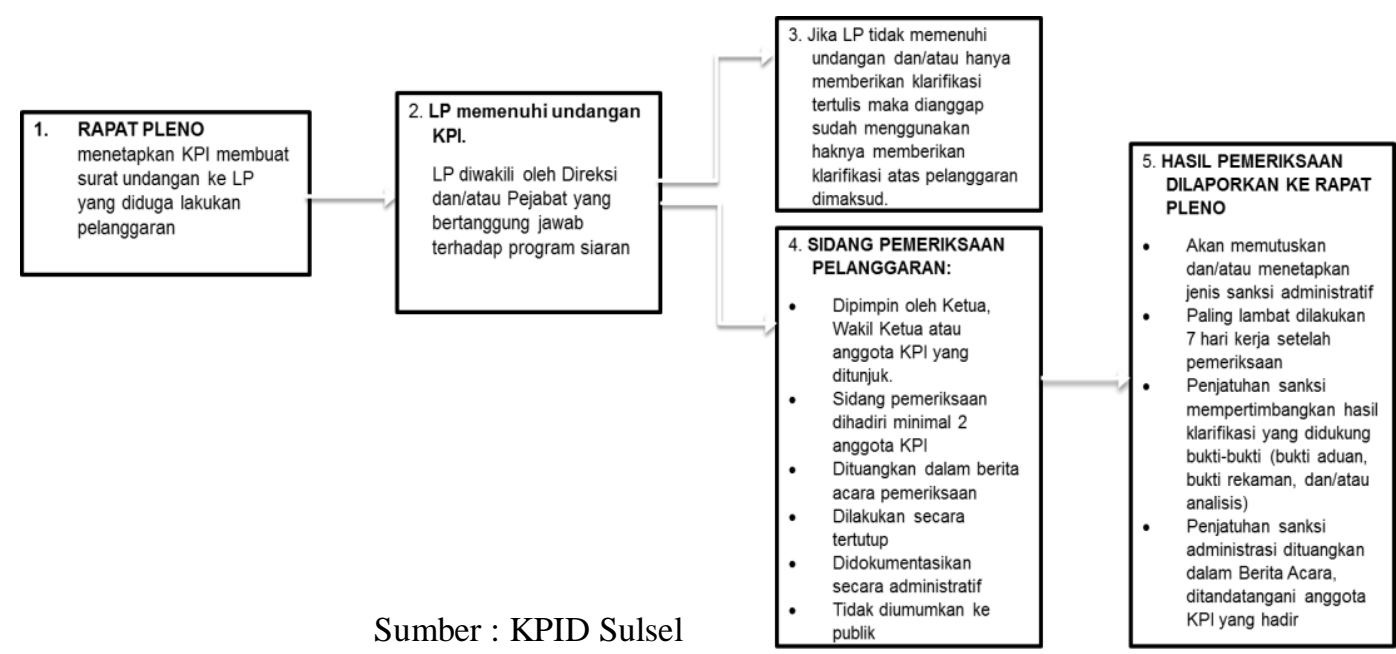

Gambar 2. Rekapitulasi Pelanggaran Penggolongan Program Siaran Periode Tahun 20142015.

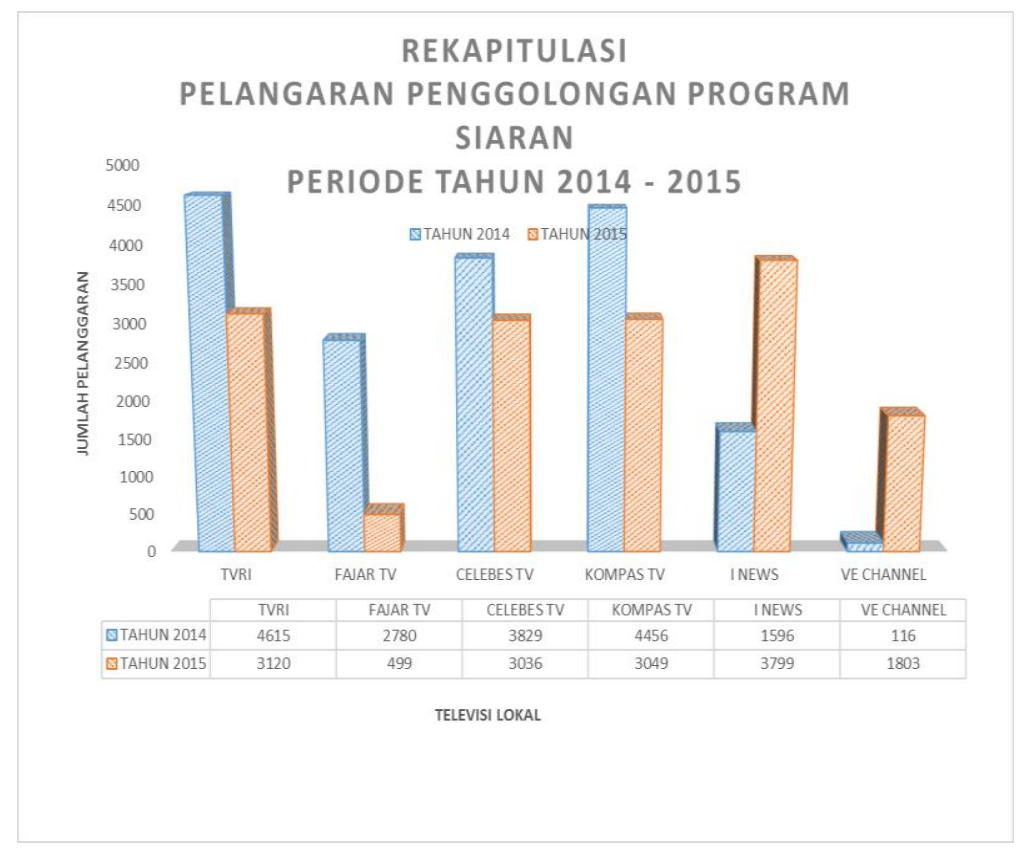

